\title{
Gestational Pattern of Heme Oxygenase Expression in the Rat
}

\author{
DORON KREISER, DOMINIQUE K. KELLY, DANIEL S. SEIDMAN, DAVID K. STEVENSON, \\ MICHA BAUM, AND PHYLLIS A. DENNERY \\ Department of Pediatrics, Stanford University School of Medicine, Stanford, California, U.S.A. [D.K., \\ D.K.K., D.K.S., P.A.D.]; Department of Obstetrics and Gynecology, Sheba Medical Center, Tel-Hashomer, \\ Tel-Aviv University, Israel [D.K., D.S.S., M.B.]
}

\begin{abstract}
Fetal growth is influenced by many intrinsic and extrinsic
factors. Our objective was to determine the pattern of heme
oxygenase (HO) expression in the pregnant rat and to study its
association with fetal growth and growth factors. Uterine tissues
were obtained from nonpregnant and from time-mated rats at 7 ,
13, 16, 19, and 21 d of pregnancy. Placental tissue was obtained
on d 13, 16, 19 and 21 of pregnancy. Tissues were evaluated for
HO activity, HO-1, HO-2, leptin and vascular endothelial growth
factor protein, and HO-1 and HO-2 mRNA. HO activity in both
the uterus and placenta peaked on d 21 of pregnancy. In the
uterus, HO-1 and HO-2 protein and total mRNA levels peaked on
d 16 of pregnancy, whereas, in the placenta, HO-1 and HO-2
protein levels peaked on d 19. Additionally, placental HO-1
mRNA peaked on d 16, but placental HO-2 mRNA declined
toward the end of pregnancy. Placental leptin and vascular
\end{abstract}
HO catalyzes the conversion of heme to bilirubin and carbon monoxide (CO). There are three isoforms of $\mathrm{HO}$, which are regulated under separate mechanisms (1). The proteins of the best-characterized isoforms, $\mathrm{HO}-1$ and $\mathrm{HO}-2$, are immunologically distinct (2). The two genes are located on different chromosomes and there is no hybridization of HO-1 to HO-2 cDNA (1). HO activity is not evenly distributed across tissues, but $\mathrm{HO}$ activity is found in most tissues (3),including the uterus and the placenta of rats and other species $(4,5)$. In human placenta, HO-1 is expressed at low levels throughout pregnancy, whereas HO-2 expression declines throughout pregnancy in the syncytiotrophoblast (6). Recent evidence suggests that $\mathrm{HO}$ functions to change vascular tone, reduce oxidative stress, and influence cellular proliferation (7-10).

Received June 8, 2001; accepted October 17, 2002.

Correspondence: Phyllis A. Dennery, Department of Pediatrics, Stanford University School of Medicine, 750 Welch Rd., \#315, Palo Alto, CA, 94304, U.S.A.; e-mail: dennery@leland.stanford.edu

Supported by the U.S.-Israel Binational Science Foundation, the American Physician Fellowship in Israel (D.K.), The National Institutes of Health (HD39248, P.A.D.) and the Mary L. Johnson Foundation of Stanford University.

DOI: 10.1203/01.PDR.0000072516.83498.07 endothelial growth factor protein levels followed a similar pattern to placental HO-1 and peaked on d 16. We conclude that there is a clear uterine and placental gestational pattern of $\mathrm{HO}$ expression in the rat. This pattern is comparable to that of vascular endothelial growth factor and leptin. (Pediatr Res 54: 172-178, 2003)

\author{
HO, heme oxygenase \\ Abbreviations \\ NO, nitric oxide \\ VEGF, vascular endothelial growth factor \\ CGMP, cyclic GMP \\ CO, carbon monoxide
}

NADPH, nicotinamide adenine dinucleotide phosphate, reduced form

The diatomic molecule $\mathrm{CO}$ is produced through the metabolic reaction of HO. This molecule shares some of the physiochemical properties of NO (11). Like NO, CO has the ability to bind to the iron atom of the heme moiety associated with soluble guanylyl cyclase, thereby activating the enzyme and increasing intracellular cGMP production. Endogenous $\mathrm{CO}$ production under physiologic conditions serves to regulate smooth muscle (12) and uterine contraction $(13,14)$, thrombocyte aggregation (15), and neurotransmission (16). Exogenously added $\mathrm{CO}$ has been shown to inhibit platelet aggregation, relax both human and rat uterine smooth muscle (13), and relax isolated blood vessel preparations by elevating intracellular levels of cGMP (3). Therefore, HO could play a role in gestation and fetal growth through $\mathrm{CO}$-mediated effects.

In both humans (17) and mutant mice (18), HO-1 deficiency is associated with growth restriction and fetal loss. The exact mechanism by which HO may mediate growth is not known, although it may be that $\mathrm{HO}$ exerts an influence on growth factors such as leptin and VEGF, which are known to be important in the fetal growth $(19,20)$. Therefore, the purpose of this study was to determine the expression of HO-1 and HO-2 at different stages of gestation and to evaluate the 
relationship of $\mathrm{HO}$ to certain growth factors important in gestation in a rat model.

\section{METHODS}

Timed pregnant Wistar rats were housed singly in a temperature-controlled room $\left(25 \pm 4^{\circ} \mathrm{C}\right)$ on a 12-h light cycle. The animals were allowed free access to food and water. All animal care was in accordance with National Institutes of Health guidelines and under Institutional Animal Care and Use Committee approval.

Uterine and placental tissues were obtained from timed pregnant Wistar rats at 13,16, 19 and $21 \mathrm{~d}$ of pregnancy, with the day when the sperm plug was observed considered as $\mathrm{d} 1$. Uterine tissue was also removed on the $\mathrm{d} 7$ of pregnancy and from nonpregnant Wistar rat females. The pregnant rats were anesthetized and killed by $\mathrm{CO}_{2}$ inhalation.

\section{Determination of HO Activity}

Measurement of HO activity in placental tissue was obtained by pooling four conceptuses per sample. Tissues were homogenized in four volumes of $0.01 \mathrm{M}$ sodium potassium phosphate buffer at $\mathrm{pH} 7.4$ and then centrifuged for $60 \mathrm{~s}$ at $12,500 \times g$. The supernatant was then analyzed for $\mathrm{HO}$ activity as previously described (21). Twenty microliters of tissue supernatant, representing $4 \mathrm{mg}$ fresh weight of tissue, were incubated in 2 -mL amber glass vials with $20 \mu \mathrm{L}$ of $1.5 \mu \mathrm{M}$ methemalbumin in $150 \mu \mathrm{L}$ BSA and $20 \mu \mathrm{L}$ of $4.5 \mathrm{mM}$ NADPH for the total reaction vials. For blank reaction vials, the NADPH was replaced with an equal volume of buffer. The vials were sealed with septum caps and placed in $37^{\circ} \mathrm{C}$ water bath for $5 \mathrm{~min}$ of temperature equilibration and then purged with $\mathrm{CO}$-free air. After $15 \mathrm{~min}$, the reactions were terminated by placing the vials on powdered dry ice $\left(-78^{\circ} \mathrm{C}\right)$. $\mathrm{CO}$ generated in the reaction medium and effused into the vials' head space was quantitated by gas chromatography with a reduction gas analyzer (Trace Analytical Inc., Menlo Park, CA, U.S.A.). Analyzer response to $\mathrm{CO}$ was recorded with an integrating recorder (CR-3A, Shimadzu Scientific Instruments Inc., Columbia, MD, U.S.A.) through measurement of peak area. The reduction gas analyzer was standardized daily with volumes of $10.8 \mu \mathrm{L}$ of CO per liter air $(482 \mathrm{nM})$. Homogenates were analyzed for protein content by the method of Lowry et al. (22) and read at $595 \mathrm{~nm}$. HO activity is defined as NADPH-dependent CO production and is calculated as the difference between the $\mathrm{CO}$ in the total and blank reaction vials. $\mathrm{HO}$ activity was expressed as mean $\pm \mathrm{SD}$ in picomoles $\mathrm{CO}$ per microgram protein per hour.

\section{Antibodies}

Polyclonal rabbit anti-rat HO-1 antibody was raised against a $30 \mathrm{kD}$ soluble HO-1 protein expressed in Escherichia coli from rat liver cDNA (23) (gift of Angela Wilks, University of California, San Francisco, CA, U.S.A.) as previously described (10). Rabbit anti-rat HO-2 antibody was obtained from Stressgen (Vancouver, BC, Canada). Rabbit anti-rat VEGF and leptin antibodies were obtained from Santa Cruz Biotechnologies (Santa Cruz, CA, U.S.A.). Horse radish peroxidase- conjugated goat anti-rabbit and anti-goat polyclonal IgG was obtained from Santa Cruz Biotechnologies.

\section{Determination of HO-1, HO-2, VEGF, and Leptin Immunoreactive Protein Levels (Western Analysis)}

Sixty microgram aliquots of uterine or placental homogenates for HO-1 and HO-2, or $180 \mu \mathrm{g}$ for VEGF and leptin, were electrophoresed on a $12 \%$ polyacrylamide gel and then transferred to polyvinylidene difluoride membrane (PVDF) (Millipore Corporation, Bedford, MA, U.S.A.). Membranes were incubated for $1 \mathrm{~h}$ with a 1:500 dilution of the primary antibody washed three times for 10 min with $0.05 \%$ Tween PBS (T-PBS) (10). Afterwards, the membranes were incubated for $1 \mathrm{~h}$ with a 1:800 dilution of anti-goat or anti-rabbit polyclonal $\mathrm{IgG}$ at room temperature. Antigen-antibody complexes were visualized with the horseradish peroxidase chemiluminescence system (ECL) according to the manufacturer's instructions (Amersham Pharmacia Biotech, Little Chalfont, Buckinghamshire, England). Equal loading of samples was verified by Coomassie blue stain. Densitometric evaluation was conducted (SGI, Sunnyvale, CA, U.S.A.) and values from each blot normalized to controls to allow for comparison between blots.

\section{Immunohistochemical Detection of HO-1 and HO-2}

Six-micron slices from pregnant rat uterus or placenta were fixed in ice-cold $100 \%$ acetone, permeabilized in $0.3 \%$ saponin in PBS, and blocked in a PBS solution containing 5\% nonfat powdered milk, $1 \% \mathrm{BSA}$, and $0.03 \%$ saponin. The slides were incubated for $1 \mathrm{~h}$ at room temperature with a rabbit anti-rat polyclonal antibody to HO-1 at a 1:20 dilution. The slides were then incubated with a 1:50 dilution of FITC-labeled goat anti-rabbit secondary antibodies (Caltag Laboratories, Burlingame, CA, U.S.A.) for $1 \mathrm{~h}$ at room temperature. Slides were then incubated with rabbit anti-rat polyclonal HO-2 antibody at a 1:20 dilution for $1 \mathrm{~h}$ at room temperature and finally incubated with Texas red-labeled goat anti-rabbit secondary antibodies at 1:50 for $1 \mathrm{~h}$. The slides were mounted with antifade reagent in glycerol buffer (Slowfade, Molecular Probes, Eugene, OR, U.S.A.) and viewed with a Nikon fluorescence microscope (Tokyo, Japan) using a confocal laser scanning unit (model 2010, Molecular Dynamics, Sunnyvale, CA, U.S.A.). Excitation was set at $488 \mathrm{~nm}$ and emission at 515-545 $\mathrm{nm}$. Images obtained here and with FITC staining were processed as anaglyphs. Negative controls for nonspecific binding, incubated with secondary antibody only, were processed and revealed no signal.

\section{Determination of HO-1 and HO-2 Total mRNA}

Plasmid and probe preparation. The plasmid pBKRHO1 was constructed in pBluescript II SK- using rat HO-1 and HO-2 cDNA fragments prepared by reverse transcriptast PCR as previously described (10). The housekeeping gene glyceraldehyde-3-phosphate dehydrogenase (G3PD) was prepared as an E. coli digest of the HHCPF19 plasmid by standard methods 
(24). Labeled probes were prepared by the random primer method (25) using ${ }^{32} \mathrm{P}-\mathrm{dCTP}$.

Northern hybridization. For HO-1 mRNA determinations, tissue samples were immediately homogenized in $4 \mathrm{M}$ guanidinium thiocyanate, quick frozen in liquid $\mathrm{N}_{2}$, and stored at $-80^{\circ} \mathrm{C}$. RNA was isolated by the guanidinium thiocyanate phenol extraction method (26) and quantitated spectrophotometrically at $260 \mathrm{~nm}$. Total RNA was electrophoresed and probed as previously described (10). Briefly, RNA (20 $\mu \mathrm{g})$ was electrophoresed on a 1.0\% agarose gel after formaldehyde denaturation. The RNA was transferred by capillary action onto filter membranes. Filter membranes were prehybridized at $42^{\circ} \mathrm{C}$ for $4 \mathrm{~h}$. The hybridization solution containing $1 \times 10^{6}$ $\mathrm{cpm} / \mathrm{mL}$ of probe $\left({ }^{32} \mathrm{P}\right.$-labeled HO-1 cDNA or HO-2 cDNA) was then added and the mixture wasallowed to incubate for $72 \mathrm{~h}$ at $42^{\circ} \mathrm{C}$. The blot was exposed against $\mathrm{x}$-ray film at $-80^{\circ} \mathrm{C}$ with intensifying screens. Autoradiographs were visualized and quantitated by densitometry and normalized to G3PD. For re-probing, membranes were stripped according to the manufacturer's protocol using boiling $0.5 \%$ SDS.

\section{Statistical Analysis}

For comparison between days of pregnancy, the null hypothesis that there was no difference between group means was tested by a single-factor ANOVA for continuous variables using the Fisher exact test for multiple groups or unpaired $t$ test for two groups (StatView 4.02, Abacus Concepts, Berkeley, CA, U.S.A.). Statistical significance was assumed at $p<0.05$.

\section{RESULTS}

Uterine $\mathrm{HO}$ activity rose significantly from d 16 of pregnancy compared with that of the nongravid uterus. The HO activity peaked on $\mathrm{d} 21$ of pregnancy (Fig. $1 A$ ). As with uterine $\mathrm{HO}$ activity, placental HO activity was significantly higher beginning on $\mathrm{d} 16$ of pregnancy $(p<0.05)$, when compared with d 13 of pregnancy and peaked on d 21 of pregnancy (Fig. $1 B)$.

In contrast to $\mathrm{HO}$ activity, uterine $\mathrm{HO}-1$ protein levels were significantly higher $(p<0.05)$ from d 16 of pregnancy compared with the nongravid uterus (Fig. 2A). Thereafter, the levels declined until d 21. Similarly, placental HO-1 protein levels were significantly higher $(p<0.05)$ on d 16 compared with d 13 of pregnancy and peaked on d 19 of pregnancy but declined on d 21 (Fig. 2A). Uterine HO-2 protein was also highest on d 16 and declined toward the end of pregnancy (Fig. $2 B$ ). As with the placental HO-1, placental HO-2 protein levels peaked on $\mathrm{d} 19$ of pregnancy but declined on $\mathrm{d} 21$ of pregnancy (Fig. 2B).

Immunohistochemical detection of $\mathrm{HO}$ protein demonstrated increased HO-1 and HO-2 protein signal in the uterine blood vessels at d 19 and a concentrated expression of $\mathrm{HO}$ in the syncytiotrophoblast region of the placenta with maximal expression at d 16 (Fig. 3, $A$ and $B$ )

As with HO-1 protein, uterine HO-1 m-RNA levels were significantly higher $(p<0.05)$ from d 13 and peaked on d 16 of pregnancy, compared with the nongravid and $\mathrm{d} 7$ uteri. Thereafter, the levels declined until d 21 (Fig. 4A). As with the uterus, placental HO-1 m-RNA levels peaked on d 16 and declined through d 21 (Fig. 4B). Uterine HO-2 mRNA levels also peaked on d 16 of pregnancy (Fig. 4C). In contrast, placental HO-2 mRNA levels declined, starting on d 19 of pregnancy, with the lowest value seen on d 21 (Fig. 4D).

We evaluated the abundance of growth factors known to play a role in the fetal growth to see whether these paralleled HO expression. Placental VEGF and leptin protein levels peaked on d 16 of pregnancy (Fig. 2, $C$ and $D$ ). This pattern approximated that of HO-1 and HO-2 protein expression.

\section{DISCUSSION}

In the pregnant rat, HO-1 and HO-2 have a gestational pattern of expression that approximates that of key growth factors. Specifically, we showed that uterine and placental $\mathrm{HO}$ protein levels were significantly elevated from d 16 to 19 . Furthermore, in the placenta there is a localized expression of $\mathrm{HO}$ in the syncytiotrophoblast region, where the synthesis of many placental growth factors occurs (27-29). As with $\mathrm{HO}$ protein levels, the erythropoietic activity of the fetal liver increases on d 16 with a decline toward the end of pregnancy (30). Additionally, $\mathrm{CO}$, a byproduct of $\mathrm{HO}$, positively influences erythropoiesis in rats (31). Furthermore, erythropoiesis is positively correlated to fetal growth in the rat (32) and the peak of erythropoietic activity and of $\mathrm{HO}$ protein levels represent the phase of maximal growth. Based on these observations, we hypothesize that HO plays a role in fetal growth.
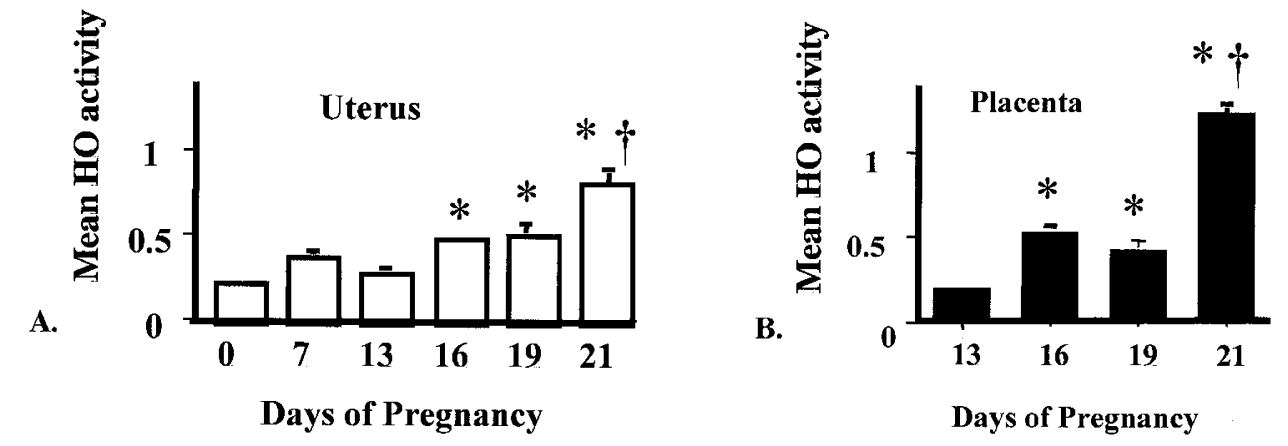

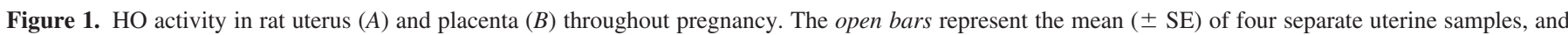

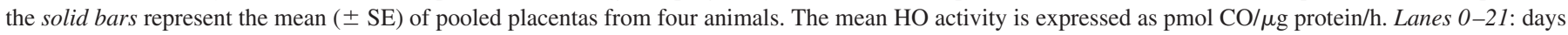
of gestation. ${ }^{*} p<0.05$ vs d 7 and $13 ; \dagger p<0.05$ vs d 16 and $19 ; \ddagger p<0.05$ vs d 0 . 

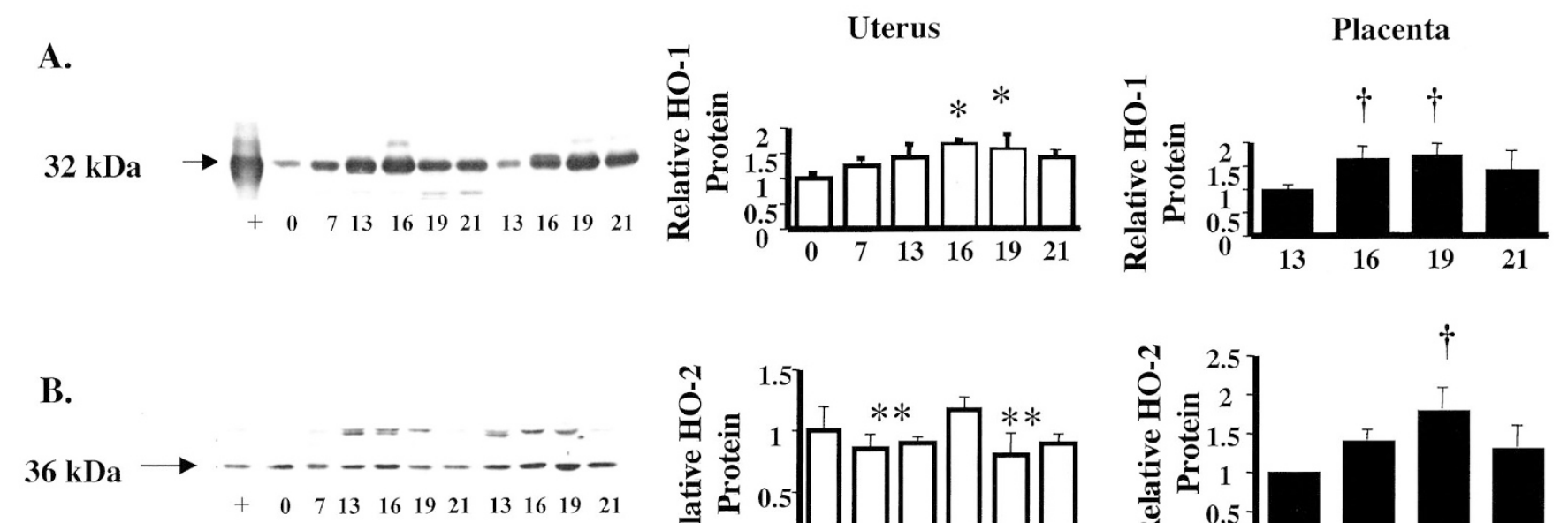

\section{Days of pregnancy}

C. $27 \mathrm{kDa}$

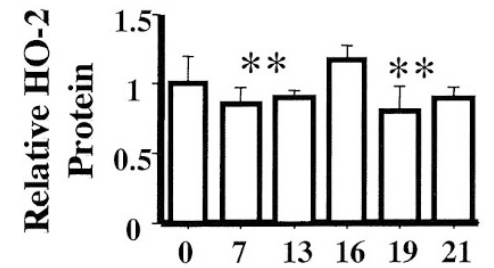

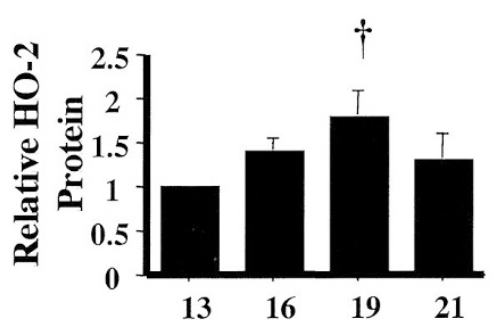

Days of pregnancy

D.
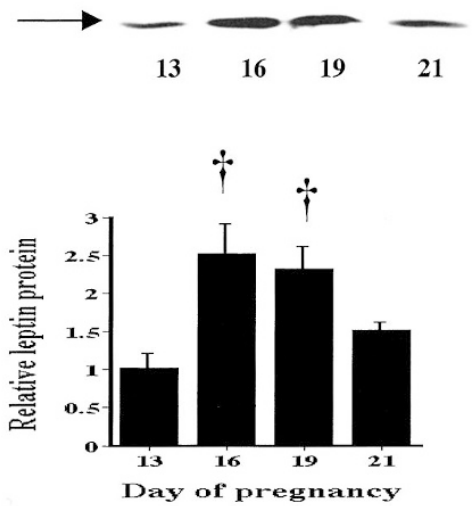

Figure 2. Immunoreactive HO-1 $(A)$, HO-2 $(B)$, VEGF $(C)$, and leptin $(D)$ proteins in the pregnant rat. For HO-1 and HO-2 $(A$ and $B)$, panels on the left are representative of four Western analyses and the densitometric evaluation is shown on the right. + : positive control derived from cobalt chloride injected adult rat liver for HO-1, and noninjected adult rat testis for HO-2. For VEGF amd leptin ( $C$ and $D)$, the upper panels are representative of four Western analyses in the placenta and the lower panels are the densitometric evaluation from these analyses. In all figures, lanes 0-21: days of gestation. Equal loading was verified by Coomassie blue staining. Densitometric values are expressed as a ratio to d 0 values (uterus) or d 13 (placenta) and represent the mean \pm SE of four separate experiments. ${ }^{*} p<0.05 v s \mathrm{~d} 0 ; \dagger p<0.05$ vs d 13 .

As with the uterine $\mathrm{HO}$ protein expression, $\mathrm{HO}-1$ and $\mathrm{HO}-2$ mRNA levels reached a peak at about d 16 of pregnancy and declined toward the end of pregnancy. In contrast, $\mathrm{HO}$ activity showed a peak on $\mathrm{d} 21$ of pregnancy. The lack of correlation between protein levels and $\mathrm{HO}$ activity may suggest posttranslational regulation of HO-1 and/or HO-2, as both contribute to the total $\mathrm{HO}$ activity. This is not unique to this model. Others have demonstrated translational activation of HO-2 in cultured neurons (33). In the neonatal lung, there also appears to be post-transcriptional activation of $\mathrm{HO}-1$ protein in hyperoxia (34).

We demonstrated that $\mathrm{HO}$ protein levels are comparable to the expression of VEGF and leptin. These factors have a clear role in fetal growth as they are found at lower levels in pregnancies complicated by intrauterine growth restriction (20, 35). Although this is merely an association, we speculate that HO may play a role in intrauterine growth. This is corroborated by a recent study from our lab demonstrating that overexpres- sion of HO-1 protein or inhibition of $\mathrm{HO}$ activity is associated with modulation of VEGF in the placenta (36). Whether CO or another byproduct of $\mathrm{HO}$ regulates growth factor expression, or whether $\mathrm{HO}$ is regulated by these growth factors is not yet clear. There are several mechanisms by which HO may alter growth factors and mediate fetal growth. First, HO generates $\mathrm{CO}$, which in turn activates guanylyl cyclase in vitro (16) and in isolated cells (12). This activation of guanylyl cyclase is similar to that observed with NO, which plays an essential role in fetal perfusion and fetal weight at delivery (37). Chronic reduction of NO production in the last trimester of pregnancy results in significant growth retardation and hemorrhagic disruption of hind limbs in rats (38). CO can also modulate p38 MAP kinase activation, leading to wide-ranging effects, including alteration of cell proliferation and apoptosis (39). Targeted disruption of HO-1 results in abnormal fetal growth as shown in the human and the mouse models $(17,18)$ and inhibition of $\mathrm{HO}$ activity by ZnPP results in decreased fetal growth (36). 
A.

HO-1
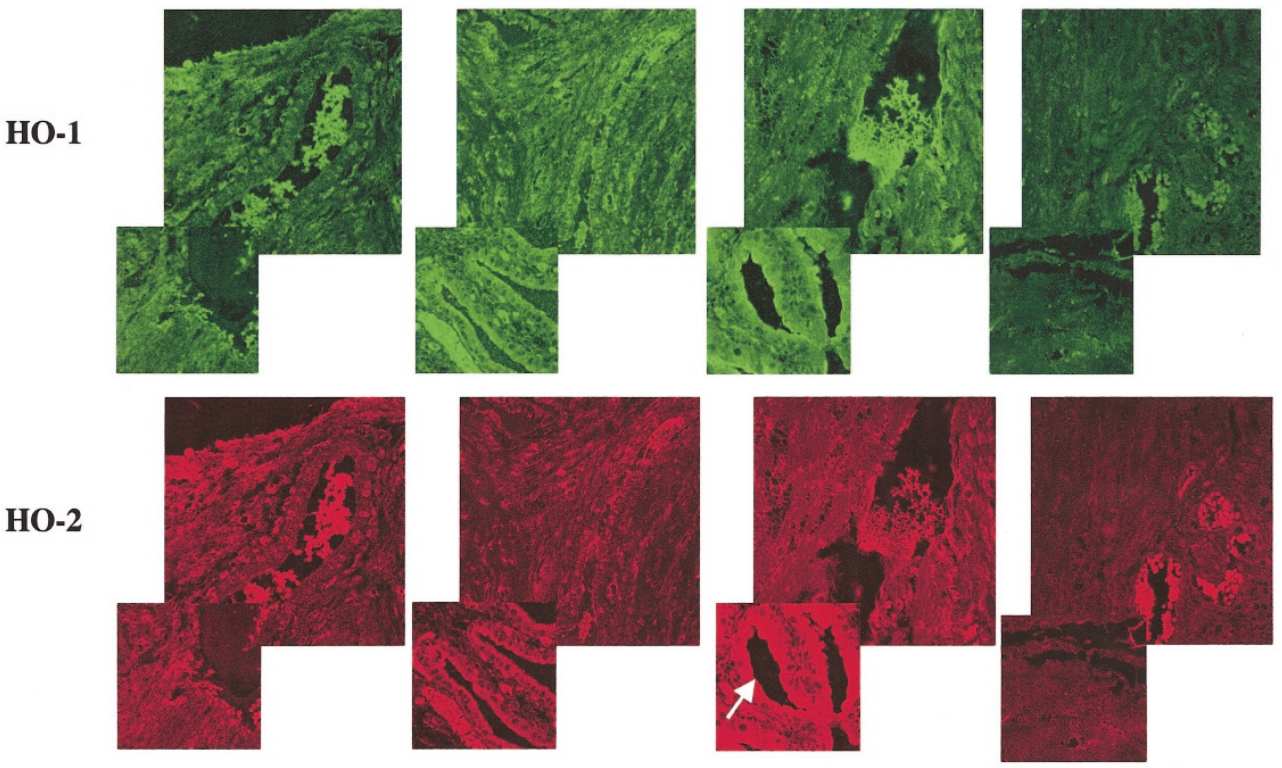

13

16

19

21

\section{Days of pregnancy}

B.
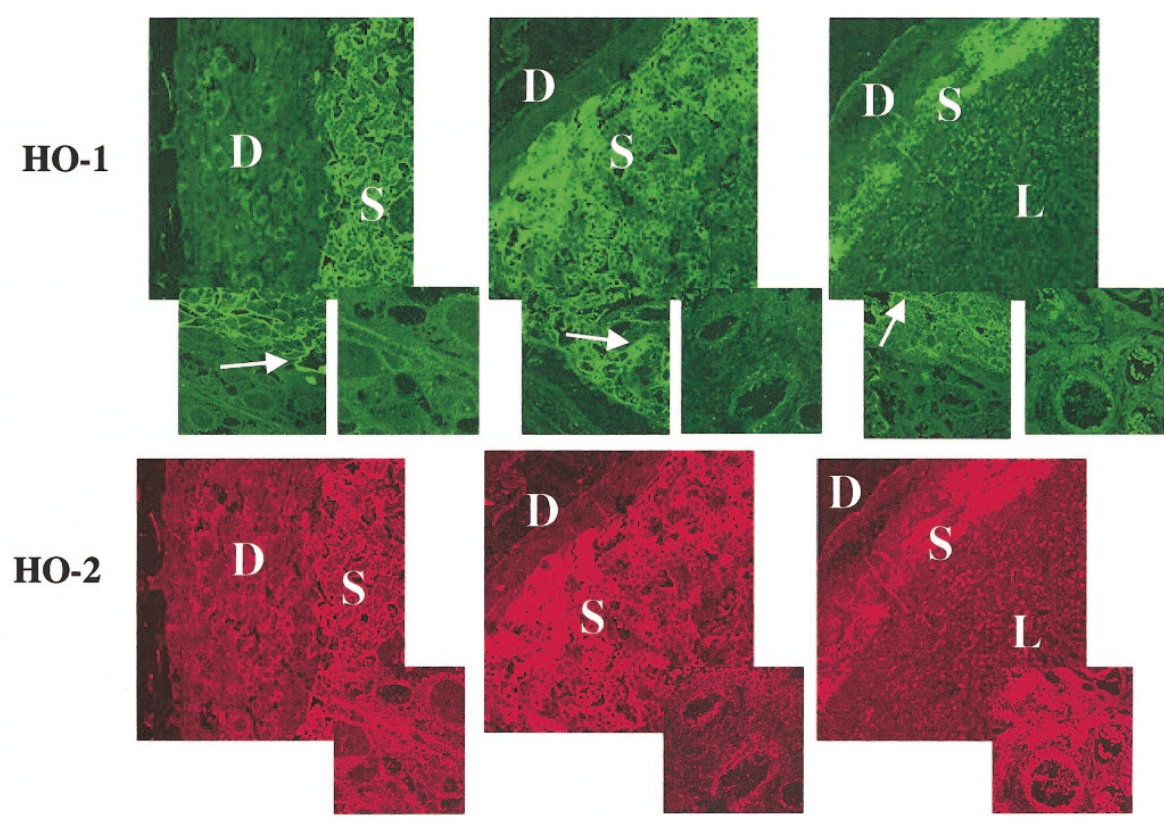

13

16

19

\section{Days of pregnancy}

Figure 3. Immunohistochemical detection of HO protein in the uterus $(A)$ and the placenta $(B)$. Tissue slices were incubated with antibody to HO-1 and HO-2, as described in the methods, and viewed with confocal laser microscopy. d 13-21 represents the gestational age. (A) Uterus: all insets show a higher magnification of a blood vessel. No increased HO signal can be observed except in the endothelial layer of the blood vessels on d 19 (arrow). (B) Placenta: the letters represent the decidua $(D)$, the syncytiotrophoblast $(S)$, and the labyrinth $(L)$. Note the strong HO signal in the syncytiotrophoblast layer compared with the other layers. In all of the panels representing HO-1 signal in the placenta, the leftmost insets demonstrate a higher magnification of the syncytiotrophoblast layer. Note that the increased HO-1 signal is found in the basement membrane (arrow). For both HO-1 and HO-2, the right insets show that the blood vessels in the labyrinth had no increased signal. 
A.

Uterus

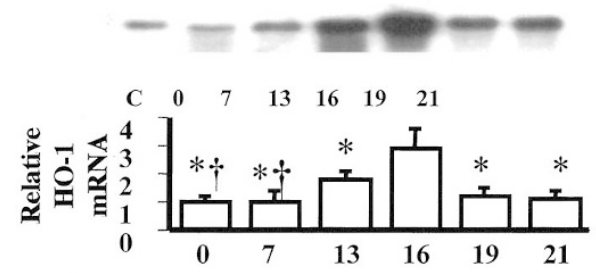

C.

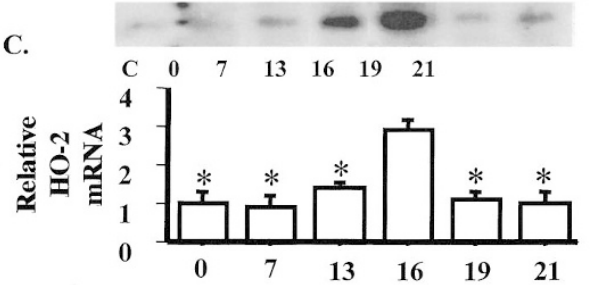

B.

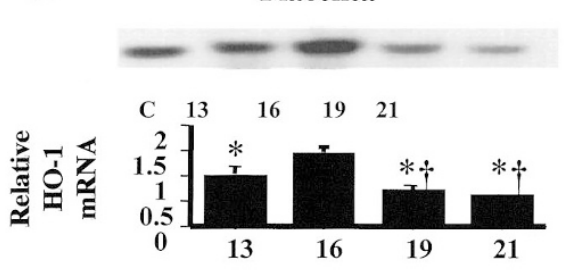

D.
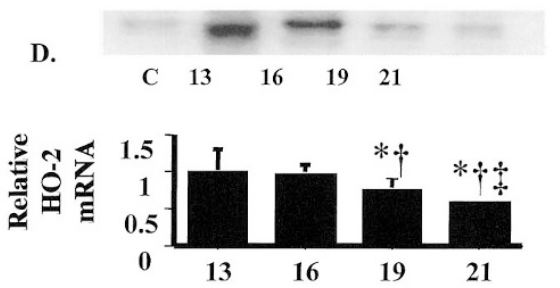

Days of Pregnancy

Figure 4. Uterine HO-1 (A), placental HO-1 mRNA $(B)$, uterine HO-2 $(C)$, and placenta HO-2 mRNA $(D)$. Upper panels: Representative of four Northern analyses. $C$ : positive control derived from adult rat liver after $\mathrm{CoCl}$ injection for HO-1 and untreated adult rat brain for HO-2. Lanes 13-21: days of pregnancy. Lower panels: Relative HO-1 mRNA in the uterus $(A)$ and placenta $(B)$ and HO-2 mRNA in the uterus $(C)$ and placenta $(D)$. The open bars represent the mean $( \pm \mathrm{SE}$ ) of four separate uterine samples and the solid bars represent the mean ( $\pm \mathrm{SE}$ ) of pooled placentas from four animals. Values are normalized to $\mathrm{d} 0$ values (uterus) or d 13 (placenta). Lanes $0-21$ : days of gestation. ${ }^{*} p<0.05 v s \mathrm{~d} 0$; $\dagger p<0.05$ vs d 13; $\ddagger p<0.05 v s \mathrm{~d} 19$.

Perhaps the $\mathrm{HO}$ byproduct $\mathrm{CO}$ is important in modulating signaling pathways involved in fetal growth

Secondly, because the reaction of $\mathrm{HO}$ results in the release of iron, this could also affect growth-related gene regulation through iron response elements (40). In a recent study, iron loading by treatment of cells with ferric salt correlated with loss of endocytic activity, which coincided with the formation of rat hepatocyte leptin-1 (41). Perhaps iron release from HO regulation is important in dictating leptin and VEGF expression. Nonetheless, the changes in HO expression during gestation are not very large in comparison to the substantial maternal iron intake during pregnancy (42), making this possibility less likely. Additionally, with iron release there is often induction of ferritin $(43,44)$, which sequesters iron. The induction of ferritin in the placenta or uterus throughout gestation has not been examined here or elsewhere.

Another possible way in which HO could affect growth is through the modulation of oxidative tone or inflammation. It is known that up-regulation of HO-1 can ameliorate oxidative stress and decrease inflammation $(45,46)$. Loss of HO-1 could result in increased susceptibility to oxidative and inflammatory injury. This could subsequently alter growth factors and fetal growth as suggested by others (47). More recently, others have documented that the HO protein devoid of activity can modulate antioxidant gene expression $(48,49)$, but the mechanism by which this occurs is not yet defined and remains to be investigated systematically.

In summary, in the pregnant rat, HO-1 and HO-2 have a gestational pattern of expression that approximates that of key growth factors important in gestation. The role of gestational HO expression in modifying fetal growth needs to be further investigated.
Acknowledgments. The authors thank Yi-Hao Weng, M.D., and Guang Yang, Ph.D., for their expert technical assistance.

\section{REFERENCES}

1. Shibahara S, Yoshizawa M, Suzuki H, Takeda K, Meguro K, Endo K 1993 Functional analysis of cDNAs for two types of human heme oxygenase and evidence for their separate regulation. J Biochem (Tokyo) 113:214-218

2. Maines MD, Trakshel GM, Kutty RK 1986 Characterization of two constitutive forms of rat liver microsomal heme oxygenase. Only one molecular species of the enzyme is inducible. J Biol Chem 261:411-419

3. Maines MD 1988 Heme oxygenase: function, multiplicity, regulatory mechanisms, and clinical applications. FASEB J 2:2557-2568

4. Odrcich MJ, Graham CH, Kimura KA, McLaughlin BE, Marks GS, Nakatsu K, Brien JF 1998 Heme oxygenase and nitric oxide synthase in the placenta of the guinea-pig during gestation. Placenta 19:509-516

5. Seidman DS, Hallak M, Kelly DK, Giudice L, Stevenson DK, Abromovici H, Dennery PA 1997 The role of carbon monoxide (CO) in the pathogenesis of pre-eclampsia. Am J Obstet Gynecol 176:S101

6. Lyall F, Barber A, Myatt L, Bulmer JN, Robson SC 2000 Hemeoxygenase expression in human placenta and placental bed implies a role in regulation of trophoblast invasion and placental function. FASEB J 14:208-219

7. Abraham NG, da Silva JL, Lavrovsky Y, Stoltz RA, Kappas A, Dunn MW, Schwartzman ML 1995 Adenovirus-mediated heme oxygenase-1 gene transfer into rabbit ocular tissues. Invest Ophthalmol Vis Sci 36:2202-2210

8. Abraham NG, Lavrovsky Y, Schwartzman ML, Stoltz RA, Levere RD, Gerritsen ME, Shibahara S, Kappas A 1995 Transfection of the human heme oxygenase gene into rabbit coronary microvessel endothelial cells: protective effect against heme and hemoglobin toxicity. Proc Natl Acad Sci U S A 92:6798-6802

9. Clark JE, Green CJ, Motterlini R 1997 Involvement of the heme oxygenase-carbon monoxide pathway in keratinocyte proliferation. Biochem Biophys Res Commun 241:215-220

10. Dennery P, Sridhar K, Lee C, Wong H, Shokoohi V, Rodgers P, Spitz D 1997 Heme oxygenase-mediated resistance to oxygen toxicity in hamster fibroblasts. J Biol Chem 272:14937-14942

11. Brune B, Ullrich V 1987 Inhibition of platelet aggregation by carbon monoxide is mediated by activation of guanylate cyclase. Mol Pharmacol 32:497-504

12. Ramos KS, Lin H, McGrath JJ 1989 Modulation of cyclic guanosine monophosphate levels in cultured aortic smooth muscle cells by carbon monoxide. Biochem Pharmacol 38:1368-1370

13. Longo M, Jain V, Vedernikov YP, Saade GR, Goodrum L, Facchinetti F, Garfield RE 1999 Effect of nitric oxide and carbon monoxide on uterine contractility during human and rat pregnancy. Am J Obstet Gynecol 181:981-988

14. Acevedo CH, Ahmed A 1998 Hemeoxygenase-1 inhibits human myometrial contractility via carbon monoxide and is upregulated by progesterone during pregnancy. J Clin Invest 101:949-955 
15. Mansouri A, Perry CA 1982 Alteration of platelet aggregation by cigarette smoke and carbon monoxide. Thromb Haemost 48:286-288

16. Verma A, Hirsch DJ, Glatt CE, Ronnett GV, Snyder SH 1993 Carbon monoxide: a putative neural messenger. Science 259:381-384

17. Yachie A, Niida Y, Wada T, Igarashi N, Kaneda H, Toma T, Ohta K, Kasahara Y, Koizumi S 1999 Oxidative stress causes enhanced endothelial cell injury in human heme oxygenase-1 deficiency. J Clin Invest 103:129-135

18. Poss KD, Tonegawa S 1997 Heme oxygenase 1 is required for mammalian iron reutilization. Proc Natl Acad Sci U S A 94:10919-10924

19. Jaquet D, Leger J, Levy-Marchal C, Oury JF, Czernichow P 1998 Ontogeny of leptin in human fetuses and newborns: effect of intrauterine growth retardation on serum leptin concentrations. J Clin Endocrinol Metab 83:1243-1246

20. Lyall F, Young A, Boswell F, Kingdom JC, Greer IA 1997 Placental expression of vascular endothelial growth factor in placentae from pregnancies complicated by pre-eclampsia and intrauterine growth restriction does not support placental hypoxia at delivery. Placenta 18:269-276

21. Vreman HJ, Stevenson DK 1988 Heme oxygenase activity as measured by carbon monoxide production. Anal Biochem 168:31-38

22. Lowry O, Rosebrough H, Farr A, Randall R 1951 Protein measurement with the folin phenol reagent. J Biol Chem 193:265-272

23. Wilks A, Ortiz de Montellano PR 1993 Rat liver heme oxygenase. High leve expression of a truncated soluble form and nature of the meso-hydroxylating species. J Biol Chem 268:22357-22362

24. Sambrook J, Fritsch E, Maniatis T 1989 Molecular Cloning: A Laboratory Manual Cold Spring Harbor Laboratory, Cold Spring Harbor, NY

25. Feinberg AP, Vogelstein B 1983 A technique for radiolabeling DNA restriction endonuclease fragments to high specific activity. Anal Biochem 132:6-13

26. Chomczynski P, Sacchi N 1987 Single-step method of RNA isolation by acid guanidinium thiocyanate-phenol-chloroform extraction. Anal Biochem 162:156-159

27. Lea RG, Howe D, Hannah LT, Bonneau O, Hunter L, Hoggard N 2000 Placenta leptin in normal, diabetic and fetal growth-retarded pregnancies. Mol Hum Reprod 6:763-769

28. Tse JY, Lao TT, Chan CC, Chiu PM, Cheung AN 2001 Expression of vascular endothelial growth factor in third-trimester placentas is not increased in growthrestricted fetuses. J Soc Gynecol Investig 8:77-82

29. Han VK, Carter AM, Chandarana S, Tanswell B, Thompson K 1999 Ontogeny of expression of insulin-like growth factor (IGF) and IGF binding protein mRNAs in the guinea-pig placenta and uterus. Placenta 20:361-377

30. Joshima H 1996 Decrease of erythropoiesis in the fetal liver of X-ray irradiated pregnant mice. J Radiat Res (Tokyo) 37:177-184

31. Prigge E, Hochrainer D 1977 Effects of carbon monoxide inhalation on erythropoiesis and cardiac hypertrophy in fetal rats. Toxicol Appl Pharmacol 42:225-228

32. Matoth Y, Zaizov R 1971 Regulation of erythropoiesis in the fetal rat. Isr J Med Sci 7:839-845

33. Dore S, Takahashi M, Ferris CD, Zakhary R, Hester LD, Guastella D, Snyder SH 1999 Bilirubin, formed by activation of heme oxygenase-2, protects neurons against oxidative stress injury. Proc Natl Acad Sci U S A 96:2445-2450

34. Dennery PA, Rodgers PA, Lum MA, Jennings BC, Shokoohi V 1996 Hyperoxic regulation of lung heme oxygenase in neonatal rats. Pediatr Res 40:815-821
35. Boguszewski M, Dahlgren J, Bjarnason R, Rosberg S, Carlsson LM, Carlsson B, Albertsson-Wikland K 1997 Serum leptin in short children born small for gestational age: relationship with the growth response to growth hormone treatment. The Swedish Study Group for Growth Hormone Treatment. Eur J Endocrinol 137:387395

36. Kreiser D, Nguyen X, Wong R, Seidman D, Stevenson D, Quan S, Abraham N, Dennery PA 2002 Heme oxygenase-1 modulates fetal growth in the rat. Lab Invest 82:687-692

37. Buhimschi I, Yallampalli C, Chwalisz K, Garfield RE 1995 Pre-eclampsia-like conditions produced by nitric oxide inhibition: effects of L-arginine, D-arginine and steroid hormones. Hum Reprod 10:2723-2730

38. Diket AL, Pierce MR, Munshi UK, Voelker CA, Eloby-Childress S, Greenberg SS, Zhang XJ, Clark DA, Miller MJ 1994 Nitric oxide inhibition causes intrauterine growth retardation and hind-limb disruptions in rats. Am J Obstet Gynecol 171:12431250

39. Brouard S, Otterbein LE, Anrather J, Tobiasch E, Bach FH, Choi AM, Soares MP 2000 Carbon monoxide generated by heme oxygenase 1 suppresses endothelial cell apoptosis. J Exp Med 192:1015-1026

40. Rouault TA, Hentze MW, Haile DJ, Harford JB, Klausner RD 1989 The ironresponsive element binding protein: a method for the affinity purification of a regulatory RNA-binding protein. Proc Natl Acad Sci U S A 86:5768-5772

41. McAbee DD, Ling YY, Stich C 1998 Iron loading of isolated rat hepatocytes inhibits asialoglycoprotein receptor dynamics and induces formation of rat hepatic lectin-1 [correction of leptin-1] (RHL-1) oligomers. Biochem J 331:719-726

42. Hindmarsh PC, Geary MP, Rodeck CH, Jackson MR, Kingdom JC 2000 Effect of early maternal iron stores on placental weight and structure. Lancet 356:719-723

43. Balla J, Nath KA, Balla G, Juckett MB, Jacob HS, Vercellotti GM 1995 Endothelial cell heme oxygenase and ferritin induction in rat lung by hemoglobin in vivo. Am J Physiol 268:L321-L327

44. Eisenstein RS, Garcia MD, Pettingell W, Munro HN 1991 Regulation of ferritin and heme oxygenase synthesis in rat fibroblasts by different forms of iron. Proc Natl Acad Sci U S A 88:688-692

45. Suttner DM, Dennery PA 1999 Reversal of HO-1 related cytoprotection with increased expression is due to reactive iron. FASEB J 13:1800-1808

46. Yang L, Quan S, Abraham NG 1999 Retrovirus-mediated HO gene transfer into endothelial cells protects against oxidant-induced injury. Am J Physiol 277:L127L133

47. Salafia CM, Ernst LM, Pezzullo JC, Wolf EJ, Rosenkrantz TS, Vintzileos AM 1995 The very low birthweight infant: maternal complications leading to preterm birth, placental lesions, and intrauterine growth. Am J Perinatol 12:106-110

48. Frankel D, Mehindate K, Schipper HM 2000 Role of heme oxygenase-1 in the regulation of manganese superoxide dismutase gene expression in oxidativelychallenged astroglia. J Cell Physiol 185:80-86

49. Hori R, Kashiba M, Toma T, Yachie A, Goda N, Makino N, Soejima A, Nagasawa T, Nakabayashi K, Suematsu M 2002 Gene transfection of H25A mutant heme oxygenase-1 protects cells against hydroperoxide-induced cytotoxicity. J Biol Chem 277:10712-10718 